\title{
Perancangan Program Penentuan Histogram Citra dengan Graphical User Interface (GUI)
}

\author{
Ima Kurniastuti ${ }^{1}$, Ary Andini ${ }^{2}$ \\ ${ }^{1}$ Program Studi Sistem Informasi Fakultas Teknik Universitas Nahdlatul Ulama Surabaya, Surabaya \\ ${ }^{2}$ Program Studi Analis Kesehatan Fakultas Kesehatan Universitas Nahdlatul Ulama Surabaya, Surabaya \\ E-mail: ima.kurniastuti@unusa.ac.id
}

\begin{abstract}
Abstrak
Dalam penelitian ini dilakukan perancangan program penentuan histogram citra yang dilengkapi dengan Graphical User Interface (GUI) sehingga pengguna lebih mudah dalam mengoperasikan program. Perancangan dilakukan dalam beberapa tahap yaitu tahap perancangan desain GUI, perancangan GUI, perancangan program dan testing program. Perancangan desain GUI bertujuan untuk menghasilkan desain GUI yang akan mempermudah programmer dalam merancang GUI program. GUI program merupakan tampilan yang akan muncul saat pengguna mengoperasikan program. Tahap perancangan program berfungsi untuk membuat source code yang berisi perintah-perintah dalam program. Tahap terakhir yang dilakukan dalam penelitian ini adalah testing program dengan menggunakan sebuah citra. Dari hasil testing program dapat disimpulkan bahwa program penentuan histogram citra berjalan dengan baik.
\end{abstract}

Kata Kunci: histogram, citra digital, citra berwarna, GUI

\section{PENDAhuluan}

Dalam dunia pemrograman, citra digital merupakan citra kontiyu $\mathrm{f}(\mathrm{x}, \mathrm{y})$ yang sudah didiskritkan baik koordinasi spasial maupun tingkat kecerahannya(Sutoyo, 2009). Informasi penting dalam citra digital dapat diketahui melalui histogram. Histogram merupakan grafik yang menggambarkan penyebaran nilai-nilai intensitas piksel dari suatu citra atau bagian tertentu di dalam citra (Putra, 2010). Informasi-informasi penting tersebut diantaranya pengkategorian citra dalam citra yang terlalu gelap, terlalu terang atau normal (tidak terlalu terang dan tidak terlalu gelap). Pengkategorian citra ini akan mempengaruhi proses pengolahan citra yang akan diterapkan pada sebuah citra. Oleh karena itu, proses penentuan histogram citra merupakan langkah penting dalam penelitian yang melibatkan citra digital.

Secara teori, citra terbagi menjadi tiga jenis yaitu citra berwarna, citra grayscale dan citra biner. Citra berwarna merupakan citra yang terdiri dari kombinasi tiga warna dasar yaitu merah (red), hijau (green), biru (blue). Setiap warna dasar memiliki intensitas sendiri dengan nilai maksimum 256 sehingga pada citra berwarna, akan memiliki tiga macam histogram yang terdiri dari histogram merah, histogram hijau dan histogram biru. Pada citra grayscale, citra hanya terdiri dari warna hitam, keabuan dan putih dan memiliki kedalaman warna 8 bit atau 256 kombinasi warna keabuan sehingga citra grayscale hanya memiliki satu buah histogram (Kurniastuti, 2017). Sedangkan pada citra biner terdiri dari dua warna yaitu hitam dan putih. Citra biner ini juga hanya memiliki satu histogram saja. Berdasarkan kompleksitas dan prioritas penggunaannya, penelitian lebih focus pada program penentuan histogram citra berwarna.

Pada penelitian ini akan dilakukan pembuatan program penentuan histogram citra yang diharapkan dapat mempermudah pengguna dalam menentukan histogram sebuah citra sehingga aplikasi ini dilengkapi dengan Graphical User Interface (GUI). Graphical User Interface (GUI) merupakan sebuah antar muka pengguna yang menggunakan metode interaksi pada piranti 
elektronik secara grafis (bukan perintah teks) antara pengguna dan komputer (Chapman, 2001). Tujuan penggunaan GUI adalah membuat program terlihat lebih simpel dan praktis bagi para pengguna. Oleh karena itu, yang perlu diperhatikan dalam pembuatan GUI adalah bagaimana menampilkan sebuah antar muka yang mudah digunakan (user friendly) sekalipun pengguna adalah orang awam yang tidak memahami kerumitan program di dalamnya (Kurniastuti, 2017).

\section{METODOLOGI}

\subsection{Alat Dan Bahan}

Alat dan bahan pada penelitian ini berfungsi sebagai pendukung dalam mencapai tujuan penelitian. Alat dan bahan yang dibutuhkan diantaranya komputer atau laptop, perangkat lunak evolus pencil, aplikasi bahasa pemrograman serta citra yaitu citra kuku yang digunakan sebagai bahan dalam penelitian ini. Citra kuku termasuk dalam citra berwarna disebabkan citra tersebut memiliki tiga warna dasar yaitu merah, hijau dan biru. Gambar 1 merupakan tampilan citra kuku.

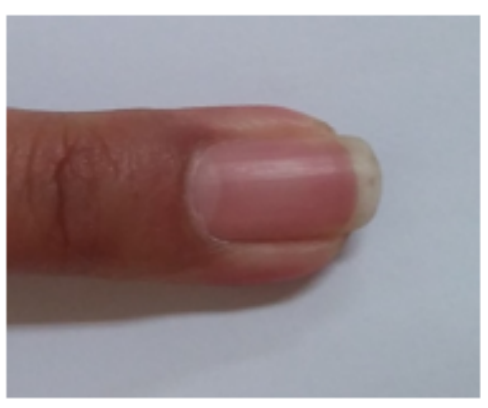

Gambar 4. Citra Kuku

2.2 Metode

Secara matematis, blok diagram penelitian ditunjukkan pada Gambar 2.

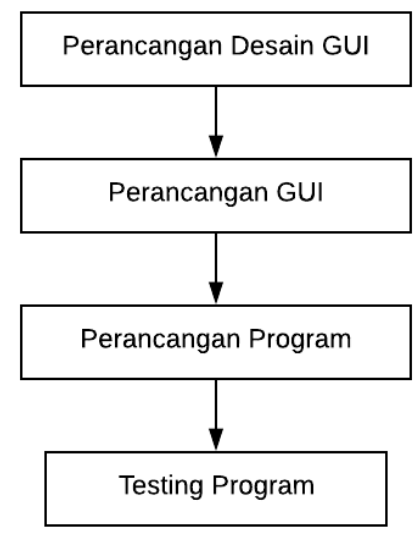

Gambar 5. Blok Diagram Penelitian

Dalam penelitian ini terdapat beberapa tahapan untuk menghasilkan program penentuan histogram citra diantaranya tahap perancangan desain GUI, tahap perancangan GUI,tahap perancangan program dan tahap testing program. Tahap pertama yang dilakukan adalah tahap perancangan desain GUI yang bertujuan untuk menghasilkan desain GUI. Dengan adanya desain GUI, penulis dapat merancang GUI program dengan mudah pada aplikasi bahasa pemrograman. Tahap selanjutnya adalah tahap perancangan GUI yang menghasilkan GUI dan 
dilakukan menggunakan aplikasi bahasa pemrograman. GUI yang dihasilkan pada tahap ini akan muncul saat pengguna menggunakan program sehingga GUI harus bersifat user friendly atau ramah pengguna. Tahap ketiga yaitu perancangan program dimana penulis mulai membuat source code program. Tahap ini merupakan tahap yang paling penting disebabkan jika tahap ini gagal maka penelitian ini tidak akan menghasilkan program. Oleh karena itu, pada tahap ini, penulis harus memastikan bahwa program telah berjalan dengan baik dengan tidak adanya kesalahan pada source code program yang telah dibuat. Untuk memastikan tidak adanya kesalahan tersebut, penulis melakukan proses build yang bertujuan untuk mengetahui adanya kesalahan atau tidak dalam source code program yang dibuat. Setelah program berjalan dengan baik, penulis perlu melakukan testing program yang merupakan tahap terakhir dalam penelitian ini. Tahap testing program menggunakan citra kuku sebagai bahan pada tahap ini.

\subsection{Histogram}

Histogram citra adalah grafik yang menggambarkan penyebaran nilai-nilai intensitas piksel dari suatu citra atau bagian tertentu di dalam citra. Dari histogram akan didapatkan frekuensi kemunculan nisbi (relative) dari intensitas pada citra tersebut. Selain itu, histogram juga menunjukkan kecerahan (brightness) dan kontras (contrast) dari sebuah citra. Oleh karena itu, histogram dapat digunakan sebagai salah satu metode pengolahan citra yang bekerja secara kualitatif dan kuantitatif (Putra, 2010). Pada citra digital yang memiliki L derajat keabuan yaitu dari 0 sampai L-1, histogram citra secara matematis dapat dihitung dengan rumus berikut:

$$
h_{i}=\frac{n_{i}}{n} \quad, i=0,1, \ldots, L-1
$$

dengan niadalah jumlah pixel yang memiliki derajat keabuan $\mathrm{i}, \mathrm{n}$ adalah jumlah seluruh piksel di dalam citra. Sedangkan secara grafis histogram ditampilkan dalam sebuah diagram batang yang ditunjukkan pada Gambar 3. Dalam penelitian ini, citra yang digunakan adalah citra berwarna maka histogram citra akan berjumlah 3 (tiga) buah yaitu histogram merah, histogram hijau dan histogram biru.

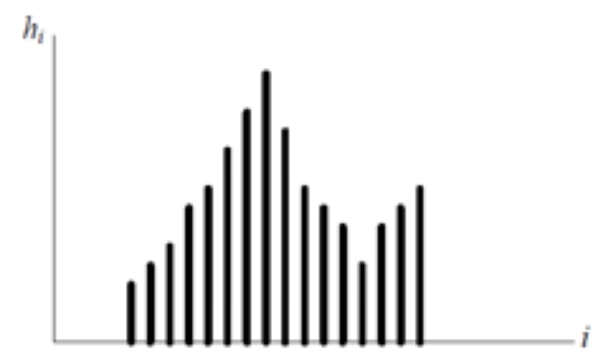

Gambar 6. Histogram Citra Secara Grafis (Munir, 2004)

\subsection{Graphical User Interface (GUI)}

Graphical User Interface (GUI) merupakan tampilan grafis yang memudahkan user atau pengguna berinteraksi dengan perintah teks (Chapman, 2001). Dengan GUI, program yang dibuat menjadi lebih user friendly sehingga user mudah menjalankan suatu aplikasi program. GUI dapat dikatakan bagus apabila program menjadi lebih mudah digunakan dengan memberikan tampilan yang konsisten dan terdiri dari control intuitif seperti pushbutton, listbox, sliders, menu dan sebagainya. 
Selain itu, GUI harus dapat dimengerti dan dapat diprediksi sehingga pengguna mengetahui apa yang harus dilakukan ketika akan melakukan sebuah proses. Misal ketika mouse diklik pada pushbutton, GUI akan melakukan proses yang terkandung di dalamnya. Fungsi dari pushbutton dijelaskan pada label pushbutton yang tertera (Kurniastuti, 2017).

\section{HASIL DAN PEMBAHASAN}

Sesuai dengan blok diagram penelitian, tahap pertama dalam penelitian ini adalah merancang desain GUI. Desain GUI dibuat dengan menggunakan aplikasi yang menyediakan fitur dalam mendesain GUI yaitu evolus pencil, sebuah perangkat lunak tidak berbayar yang menyediakan fitur GUI baik desktop maupun mobile (Evolus, 2012). Karena focus penelitian ini adalah citra berwarna maka histogram dari citra berwarna akan berjumlah 3 (tiga) buah berdasarkan tiga warna dasar yaitu merah, hijau dan biru. Hal ini menyebabkan program memiliki tiga buah GUI sehingga secara tidak langsung, desain GUI akan berjumlah tiga buah juga. Pada Gambar 4 hingga Gambar 6 secara berturut-turut menampilkan desain GUI histogram merah, histogram hijau dan histogram biru.

Pada desain GUI, terdapat dua buah kotak, satu tabel dan beberapa tombol yang memiliki fungsi berbeda-beda. Dua buah kotak tersebut berfungsi untuk menampilkan citra dan histogram secara grafis, tabel digunakan untuk menampilkan data histogram dalam bentuk tabel yang memiliki dua kolom yaitu intensitas dan jumlah piksel sedangkan beberapa tombol yaitu tombol open, tombol reset, tombol proses dan tombol exit berfungsi untuk mempermudah pengguna dalam menggunakan program. Tombol open memiliki fungsi untuk membuka atau mengambil citra yang tersimpan di komputer untuk diproses pada program. Tombol reset berfungsi untuk mereset atau menghapus tampilan citra, histogram dan tabelpada GUI sehingga program siap digunakan kembali untuk citra berikutnya. Tombol proses adalah tombol yang digunakan untuk menentukan histogram citra yang menimbulkan munculnya histogram dan data histogram pada tabel. Tombol terakhir yaitu tombol exit berfungsi untuk keluar dari program jika proses telah selesai dilakukan.

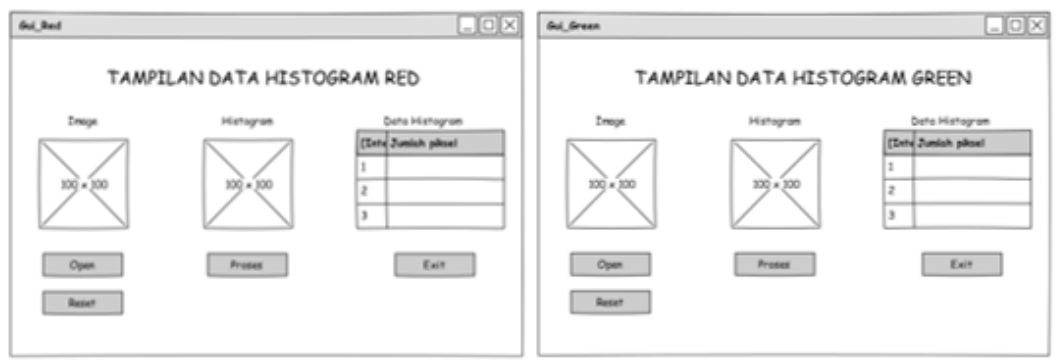

(a)

(b)

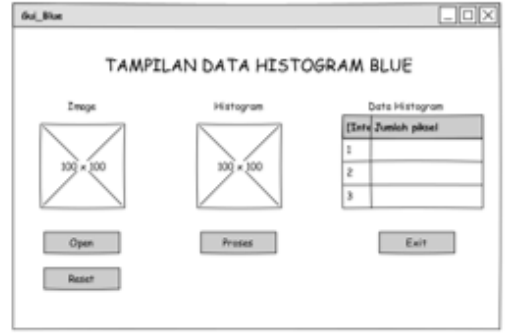

(c)

Gambar 7. Desain GUI (a) Histogram Merah (b) Histogram Hijau (c) Histogram Biru

Pada tahap selanjutnya yaitu perancangan GUI, desain GUI yang telah dibuat akan ditransformasi ke dalam GUI program seperti yang ditunjukkan pada Gambar 5 hingga Gambar 
7. Tampilan GUI program akan muncul pada saat pengguna menggunakan program. GUI dibuat sesederhana mungkin untuk mempermudah pengguna dalam mengoperasikan program yang telah dibuat.

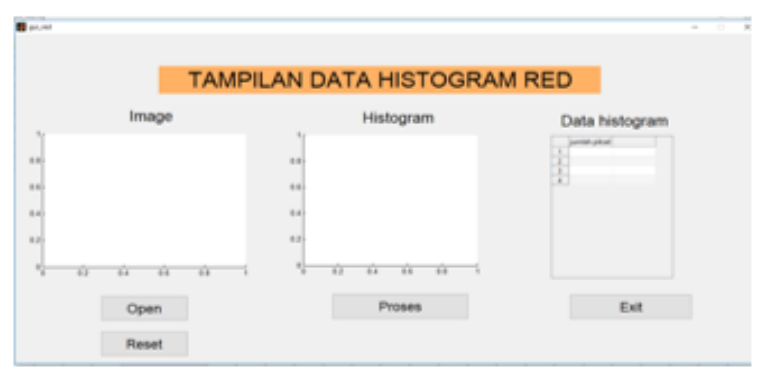

Gambar 8. GUI Histogram Merah

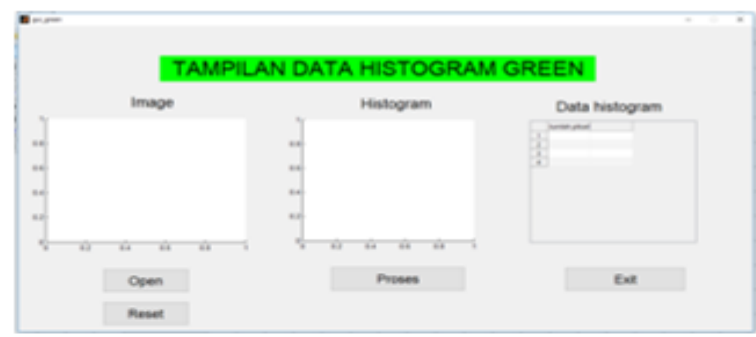

Gambar 9. GUI Histogram Hijau

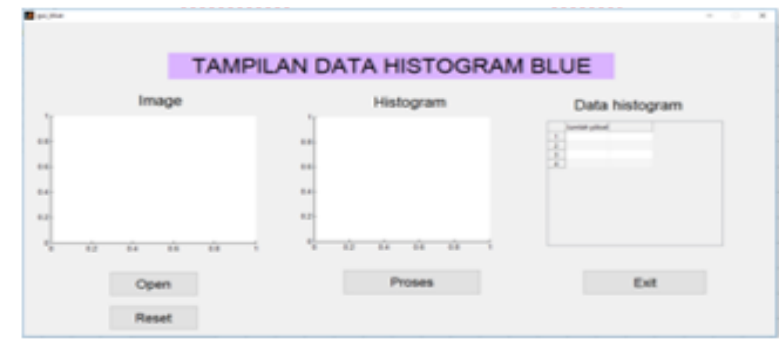

Gambar 10. GUI Histogram Biru

Dalam perancangan program, penulis membuat source code pada tiap-tiap tombol pada GUI program sehingga tombol dapat berfungsi dengan baik. Dengan fungsi yang berbeda pada tiap tombol, maka source code pada tombol tersebut juga berbeda. Karena tombol proses merupakan tombol paling penting dalam program ini, maka penulis hanya menampilkan source code untuk tombol tersebut yang ditunjukkan pada Gambar 8. Pada source code tombol proses terdiri dari tujuh baris yang diawali dengan membaca citra pada axes1. Kemudian dilanjutkan dengan menghitung intensitas 1-256 untuk warna dasar biru. Hasil perhitungan akan disimpan sebagai sebuah data pada tabel yang muncul pada GUI sebagai data histogram dan data tersebut ditampilkan dalam bentuk grafik yang dikenal dengan histogram.

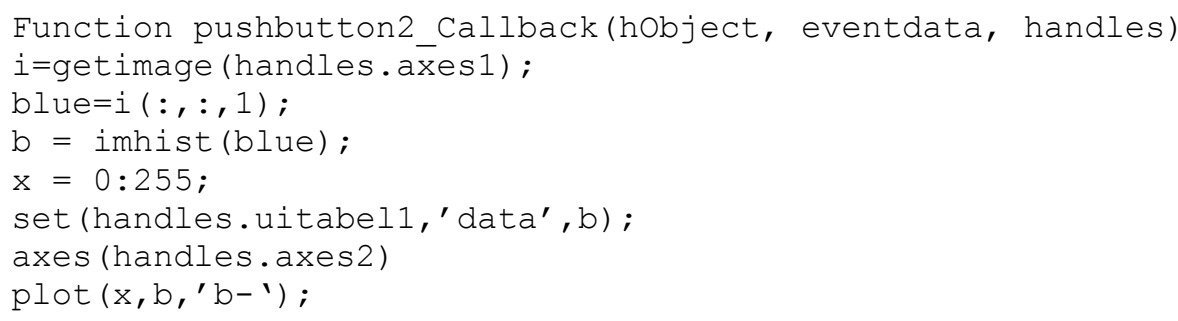

Gambar 11. Source code program 
Tahap terakhir dalam penelitian ini adalah testing program yang menggunakan citra kuku sebagai citra testing. Tampilan testing program ditunjukkan pada Gambar 9 sampai Gambar 11. Pada ketiga gambar tersebut menunjukkan bahwa program penentuan histogram merah, hijau dan biru berhasil menentukan histogram citra dengan munculnya histogram pada axes dan data histogram pada tabel. Meski begitu, penelitian ini masih memiliki kekurangan yaitu karena histogram berjumlah tiga buah maka pengguna harus membuka masing-masing GUI secara manual. Oleh karena itu perlu dilakukan pengembangan berupa GUI menu utama yang akan memberikan pilihan bagi pengguna untuk memilih proses penentuan histogram merah, hijau atau biru. Selain itu, dengan adanya GUI menu utama pengguna hanya perlu membuka satu GUI yaitu GUI menu utama yang akan terhubung ke GUI histogram merah, hijau dan biru.

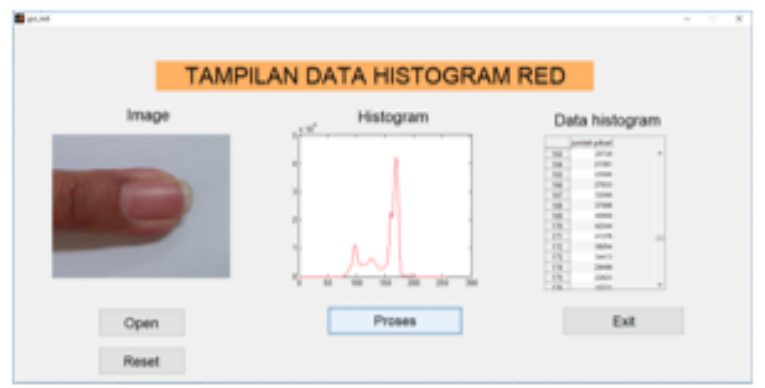

Gambar 12. Tampilan Testing Program Histogram Merah

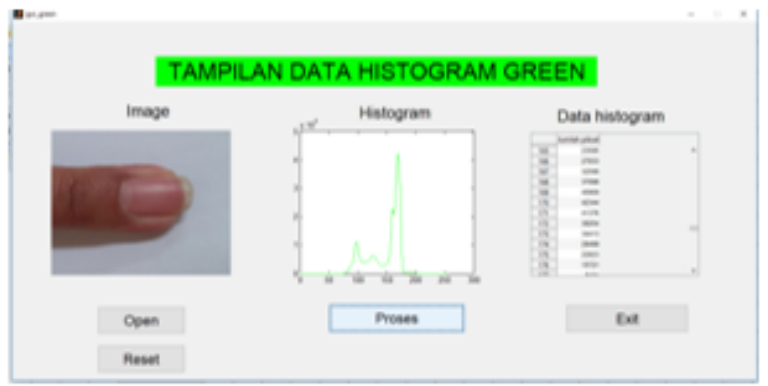

Gambar 13. Tampilan Testing Program Histogram Hijau

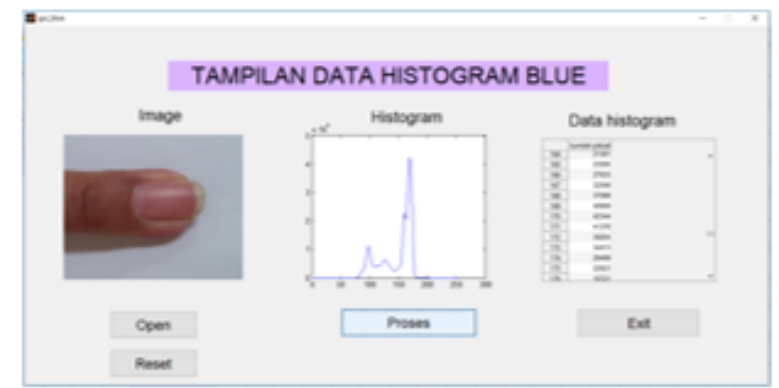

Gambar 14. Tampilan Testing Program Histogram Hijau

\section{KESIMPULAN}

Pada penelitian ini dapat disimpulkan bahwa program penentuan histogram citra dapat dilakukan melalui beberapa tahapan yaitu perancangan desain GUI, perancangan GUI, perancangan program dan testing program. Dari hasil testing program didapatkan bahwa program berhasil menentukan histogram citra pada tiga warna dasar yaitu merah, hijau dan biru. Selain itu, program juga menampilkan histogram secara grafik dan detail yang ditampilkan pada tabel. Untuk 
pengembangan selanjutnya diharapkan adanya GUI menu utama yang akan menghubungkan ketiga GUI tersebut.

\section{UCAPAN TERIMA KASIH}

Penelitian ini merupakan bagian dari penelitian yang mendapat hibah dari Kemenristekdikti berupa Penelitian Dosen Pemula (PDP) pada tahun 2018.

\section{DAFTAR PUSTAKA}

[1] Stephen J. C. Matlab Programming for Engineers. Brooks Cole. Amerika Serikat. 2001.

[2] Evolus, Pencil. 2012. Top Features of Pencil. http://pencil.evolus.vn.

[3] Ima K, Tri Deviasari W. 2017. Perbaikan Citra X-ray Gigi Menggunakan Contrast Stretching. Technology Science and Engineering Journal. 2017; 1(1): 8-13.

[4] Rinaldi M. Pengolahan Citra Digital dengan Pendekatan Algoritmik. Bandung: Penerbit Informatika. 2004.

[5] Darma P. Pengolahan Citra Digital. Penerbit Andi. Yogyakarta. 2010.

[6] T. Sutoyo. Teori Pengolahan Citra Digital. Semarang: Andi Yogyakarta dan UDINUS. 2009. 